\title{
Når vi snakker om gener
}

\author{
Utviklingen i medisinsk genetikk skjer hurtig og krever nye ord og begreper. Faget er et eksempel på at man \\ ofte har klart å finne gode norske avløserord.
}

Normal genetisk variasjon kalles polymorfisme. Den mest kjente polymorfismen er antakelig blodgruppetypene ABO. Genetisk polymorfisme innebærer tilstedeværelse av to eller flere alternative utgaver (alleler) av et bestemt gen, der den mest sjeldne utgaven forekommer hos minst $1 \%$ av befolkningen (1). Den enkleste polymorfismen består av en variasjon i ett enkelt nukleotid og kalles enkeltnukleotidpolymorfisme (single nucleotide polymorphism, SNP) (2). Pussig nok kalles både selve varianten (allelet) og det overgripende fenomenet (genetisk variasjon) genetisk polymorfisme (sjeldnere polymorfi), på tross av at -isme vanligvis viser til noe abstrakt, slik som lære, retning eller doktrine (3). Betegnelsen polymorf variant/allel eller genetisk normalvariant ville vært mer korrekt.

Begrepet homozygot (av gresk homos, «samme», og zygotos, «sammenbinding») betegner status med to identiske arveanlegg et gitt sted på et par av kromosomet (4). En person som f.eks. har fått blodtype A-anlegget både fra mor og far, er homozygot for A(-allelet). Den avledede substantivformen blir vanligvis betegnet som homozygositet hos en gitt pasient, trolig etter det engelske homozygosity eller det tyske Homozygosität. Fenomenet i videre forstand kalles også homozygoti, især innen andre biologiske fagområder.

Et gen består av introner og eksoner, og det er bare informasjon i eksonene som overføres fra DNA til mRNA. Termene eksoner og introner kommer fra de engelske exons og introns. Hybridformer som «eksons» og «introns» på norsk er slurv. Ekson og intron brukes som flertallsform i noen miljøer, men det vanlige er eksoner og introner i flertall.

\section{Nye mutasjoner og genspleising}

En mutasjon er per definisjon en varig endring $i$ arvematerialet, som kan innebære at den kan nedarves til neste generasjon. Imidlertid trenger den ikke å være nedarvet. En mutasjon som ikke kan gjenfinnes hos foreldrene betegnes som nyoppstått, eller de novo, hos pasienten. En ny mutasjon, derimot (engelsk: novel), brukes om en bestemt mutasjon som ikke er rapportert tidligere.

Det kan skilles mellom ulike typer mutasjoner etter hvilken effekt de har på DNAsekvensen. Mens en mutasjon av typen substitusjon innebærer erstatning av et enkelt nukleotid og ikke har konsekvenser for resten av DNA-tråden, vil en leserammemutasjon føre til forskyvning i rekken, slik at alle tripletter etter den som ble rammet kommer i «utakt» med referansesekvensen. Spleise(sete)mutasjoner påvirker, som navnet sier, genspleisingen, oftest ved å ramme genets spleisesete i overgangen mellom introner og eksoner. I dette tilfellet har direkte oversettelse fra engelsk gitt oss et godt, norsk ord midt $i$ den spesielle nomenklaturen, et ord som i tillegg kan forbindes med godt håndverk. Spleising betegner prosessen der de fragmentene som er tilbake etter at sekvensen er splittet opp og intronene fjernet blir skjøtet sammen til mRNA (5) (fig 1). Ordet spleising kom til norsk via det engelske splicing, som også betyr å skjøte.

Når ett mutert gen er tilstrekkelig for å fremkalle en tilstand, kalles tilstanden monogen (engelsk: monogenic disorder eller single gene disorder). Med ny teknologi har muligheten for å identifisere digene tilstander fått fornyet oppmerksomhet (6). Det har lenge vært usikkerhet om eksistensen av ren polygen arv (engelsk: polygenic), da man knapt kjenner eksempler på tilstander som krever bidrag fra flere gener der ikke også miljøet spiller en rolle. I stedet for polygen arv snakker vi heller om multifaktorielle tilstander.

\section{Kopitallsvariasjon}

Store deler av vårt arvemateriale er langt mer forskjellig mellom friske individer enn hva man tidligere hadde regnet med $(7,8)$. Strukturelle forskjeller i kromosomene kan medføre ulike doser av arvestoff hos friske personer, et fenomen som kalles kopitallsvariasjon på norsk (copy number variation, $\mathrm{CNV}$ ). Kopitallsvariasjon ble først beskrevet i 1991 og er definert som DNA-segmenter i størrelsesorden 1 kilobase opptil noen få megabaser som finnes med et variabelt antall kopier i forskjellige individer (7). Ikke sjelden, selv blant genetikere, brukes i stedet ordet kopinummervariasjon. Denne oversettelsesfeilen har antakelig oppstått

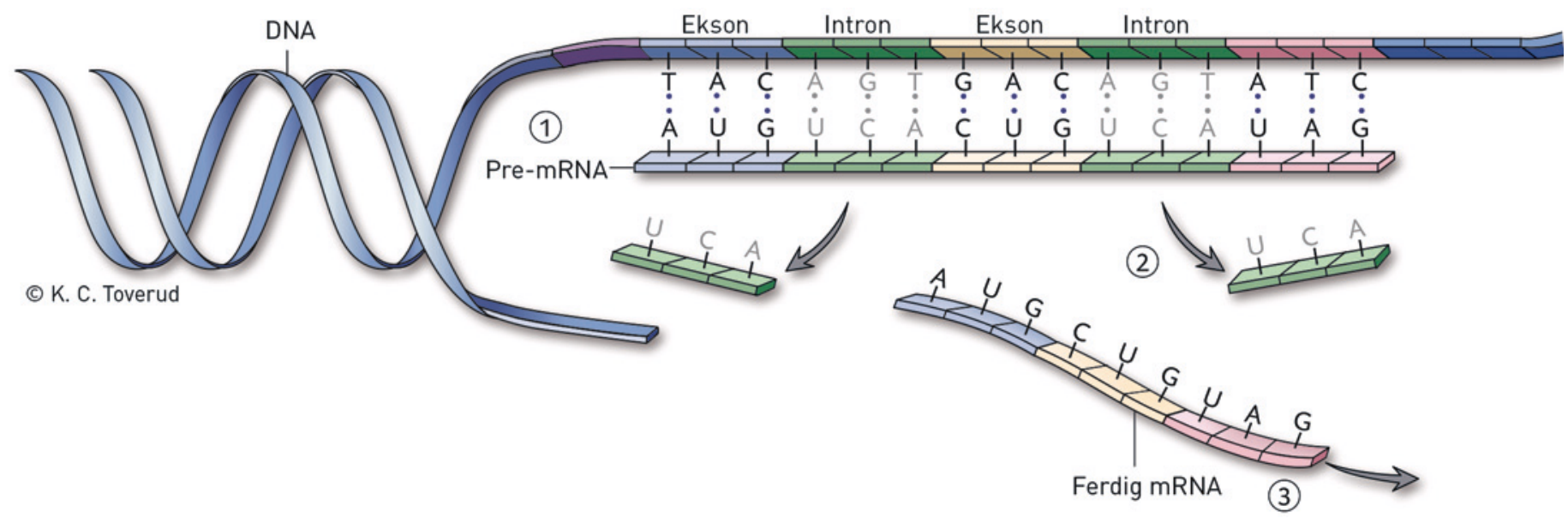

Figur 1 Genspleising. Når DNA transkriberes til mRNA, gir rekkefølgen av nukleotider (sekvensen) først opphav til et pre-mRNA-molekyl med komplementær sekvens. Deretter blir sekvensen fra intronene klippet bort av enzymer i cellekjernen. Sekvensen fra eksonene sammenføyes - spleises - til et ferdig mRNA-molekyl 
fordi ordet number på engelsk betyr både «tall» og «nummer» på norsk. «Copy number» henspiller på antall kopier av et gen eller en gensekvens (som ikke er nummerert fra naturens side!).

Ingen av leserne kan ha unngått å få med seg at det gjennom nye teknologiske fremskritt er blitt mulig å sekvensere enorme mengder arvestoff på én gang, for eksempel hele genomet (helgenomsekvensering) eller bare den proteinkodende delen (eksomsekvensering). Kjært barn har mange navn, og den nye metoden blir i dag kalt massiv parallell sekvensering (etter teknikken), høykapasitetssekvensering (high throughput sequencing, HTS) (etter yteevnen), eller nestegenerasjonssekvensering (next generation sequencing) (etter forventet anvendelse). Hvilken betegnelse vil få feste i tiden fremover? Det eneste som er sikkert, er at betegnelsen nestegenerasjonssekvensering om få år vil ha mistet sin nåværende betydning.

\section{Benedicte Paus}

benedicte.paus@ous-hf.no

Oslo universitetssykehus

og

Universitetet i Oslo

Benedicte Paus (f. 1960) er spesialist i medisinsk genetikk, overlege og professor.

\section{Litteratur}

1. Børresen-Dale A-L, Dissen E. Polymorfisme.

I: Store medisinske leksikon. https://sml.snl.no/ polymorfisme (22.2.2015).

2. Bjørheim J, Ødegaard R. Enkeltnukleotidpolymorfisme. Tidsskr Nor Lægeforen 2005; 125: 316.

3. Isme. I: Store norske leksikon.

https://snl.no/-isme (22.2.2015).

4. Heiberg A. Homozygot. I: Store medisinske leksikon. https://sml.snl.no/homozygot (22.2.2015)

5. Kristensen T. RNA-spleising. I: Store norske leksikon. https://snl.no/RNA-spleising (22.2.2015).

6. Schäffer AA. Digenic inheritance in medical genetics. J Med Genet 2013; 50: 641-52.

7. Barøy T, Misceo D, Frengen E. Strukturell variasjon i genomet bidrar til variasjon i egenskaper. Tidsskr Nor Legeforen 2008: 128: 1951-5.

8. Riggs ER, Ledbetter DH, Martin CL. Genomic variation: Lessons learned from whole-genome CNV analysis. Curr Genet Med Rep 2014; 2:

$146-50$.

Mottatt 26.2. 2015 og godkjent 17.3. 2015. Redaktør: Marit Skaar Fjellhaug. 